\title{
When Beneficial Biofilm on Materials Is Needed: Electrostatic Attachment of Living Bacterial Cells Induces Biofilm Formation
}

\author{
Dmitrii Deev ${ }^{1,2}$, laroslav Rybkin ${ }^{1,2,3,4}$, Tomaž Rijavec ${ }^{1}$ and Aleš Lapanje ${ }^{1 *}$

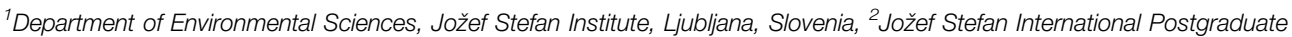 \\ School, Ljubljana, Slovenia, ${ }^{3}$ Remote Controlled Theranostic Systems Lab, Institute of Nanostructures and Biosystems, Saratov \\ State University, Saratov, Russia, ${ }^{4}$ Department of Reactive Transport, Institute of Resource Ecology, Helmholtz-Zentrum \\ Dresden-Rossendorf, Leipzig, Germany
}

OPEN ACCESS

Edited by:

Marina T. Milenković,

University of Belgrade, Serbia

Reviewed by:

Joanna Mystkowska,

Bialystok University of Technology,

Poland

Francois Malherbe,

Swinburne University of Technology,

Australia

Ajar Nath Yadav,

Eternal University, India

*Correspondence:

Aleš Lapanje

ales.lapanje@ijs.si

Specialty section:

This article was submitted to

Biomaterials,

a section of the journal

Frontiers in Materials

Received: 31 October 2020

Accepted: 22 April 2021

Published: 07 May 2021

Citation:

Deev D, Rybkin I, Rijavec T and Lapanje A (2021) When Beneficial

Biofilm on Materials is Needed:

Electrostatic Attachment of Living

Bacterial Cells Induces

Biofilm Formation.

Front. Mater. 8:624631.

doi: 10.3389/fmats.2021.624631
Bacterial attachment is crucial in many biotechnological applications, but many important bacterial strains cannot form biofilms. Biofilms can damage materials, and current strategies to manage biofilms are focused on inhibition and removal of biofilm. Biofilm formation is inevitable when materials are exposed to microbes and instead of biofilm prevention, we propose management of microbial composition by formation of biofilms with beneficial microbes. Since bacteria need to overcome a high repulsive force to attach to the surface and later to grow and multiply on it, electrostatic modification of the surfaces of cells or the material by polyelectrolytes (PE) was used in our approach, enabling efficient attachment of viable bacterial cells. Since highly positively charged PEs are known to be bactericidal, they were acetylated to reduce their toxicity, while preserving their net positive charge and ensuring cell viability. In our study bacterial strains were selected according to their intrinsic capability of biofilm formation, their shape variety and cell wall structure. These strains were tested to compare how the artificially prepared vs. natural biofilms can be used to populate the surface with beneficial bacteria. Using an artificial biofilm constructed of the potentially probiotic isolate Bacillus sp. strain 25.2. M, reduced the attachment and induced complete inhibition of E. coli growth over the biofilm. This study also revealed that the modification of the surfaces of cells or material by polyelectrolytes allows the deposition of bacterial cells, biofilm formation and attachment of biofilm nonforming cells onto surfaces. In this way, artificial biofilms with extended stability can be constructed, leading to selective pressure on further colonization of environmental bacteria.

\section{Keywords: artificial biofilms, polyelectrolytes (PEs), cell encapsulation, cell surface modification, biofilm} management

Abbreviations: Ac-PEI, acetylated PEI; ELS, electrophoretic light scattering; emGFP, emerald green fluorescent protein; EPS, extracellular polymeric substance; gfp, green fluorescent protein; LPS, lipopolysaccharide; MQ, milliQ water; NB1, nutrient broth; OD, optical density; PE, polyelectrolyte; PEI, polyethyleneimine; RT, room temperature; SI, supplementary information. 


\section{INTRODUCTION}

The detrimental effects of bacterial biofilms include surface biofouling and bio-corrosion making biofilms a threat to human health, environmental protection and industrial manufacturing costing more than $\$ 500$ billion per year (Alberte et al., 1992; Vigneron et al., 2018). The development of new strategies for the mitigation of biofilm formation is consequently the main priority in applied research. In most of the conventional approaches, attempts are made either to prevent the attachment of microbes, inhibit their growth, or even kill the cells after their contact with the surface. Studies have shown that structuring the surface (Lorenzetti et al., 2015; Linklater et al., 2020), applying metal oxide films (Upritchard et al., 2007), or inhibiting the functioning of adhesins (Bouckaert et al., 2005) all decrease the efficiency of bacterial attachment to the surface.

Although the current strategies preventing biofilm formation can be very effective for several days, solutions that would work in the long term have, to the best of our knowledge, not been developed to date. One of the major justifications for short-lived antibiofilm coatings is that a clean surface that is exposed in the environment or a closed microbial system, becomes immediately covered by a conditioning film (Dexter et al., 1975; Schneider 1997). This converts the original, less-hospitable or even antimicrobial surface to a surface that attracts cells and promotes their attachment (Palmer et al., 2007). Although biofilm formation on surfaces is an inevitable process, it can nevertheless be beneficial, which is demonstrated in cases such as water processing plants (Chaali et al., 2018), associations between plants and microbes in agricultural systems (Ghiasian 2020) and biofilm-based solid state fermentation processes (Cheng et al., 2010). Particularly in the latter, the benefits of biofilms are manifested by reduced microbial contamination of the fermentation process and the related need to renew cell biomass between fermentation cycles.

On the basis of the accumulated knowledge of the dynamics of biofilm development, we propose a shift of the biofilm removal paradigm. Rather than considering biofilms as undesirable structures that should be eradicated, we propose the onset of biofilm formation is used as an opportunity to construct a biofilm composed of protective bacteria that are not detrimental to the material. By selecting the first colonizers of the surface, we affect the development and composition of the biofilm structure, possibly making it become beneficial. A biofilm composed of desirable bacteria can protect the surface from corrosion, prevent the attachment of pathogenic bacteria and also be an integral part of the biotechnological process driven by the attached microbial biomass. In support of our hypothesis, studies of stainless steel surfaces (Oliveira et al., 2019), teeth (Marsh et al., 2011) and the urinary tract (O’May et al., 2008) have all shown that the presence and activity of one type of microbe is a prerequisite for the attachment and growth of a different sort of microbe, influencing the biofilm formation processes. Each microbe that becomes a part of the biofilm is contributing to its structure via the following mechanisms: 1) surface receptors enable physical interactions between the attached cells and compatible microbes attempting to populate the surface (Bucci et al., 2011; Liu et al., 2017), further ensuring new physical interactions with other types of bacteria, such as anaerobic bacteria (Brooks et al., 1997), 2) selective conditions, such as pH or oxygen levels (Zuo 2007; Jakubovics 2015) provide the optimal conditions for the survival of strains that are sensitive to these factors (Bradshaw et al., 1998), and 3) a selective environment caused by extracellular metabolites can inhibit or promote the growth of other bacteria (Stadler et al., 2010).

In support of our hypothesis, Rijavec et al., 2019 have shown that the use of artificial biofilms consisting of a few selected strains can successfully inhibit the attachment and the growth of bacteria associated with microbially induced corrosion during exposure of about a month in environmental conditions. However, in the complex artificial biofilm of the previously described solution (Rijavec et al., 2019), each part of the artificial structure, the hydrophobic elastomer, the polyelectrolyte (PE) matrix, or the selected antibacterialproducing bacteria, can contribute to the observed shift in the composition of the microbial community. It is thus important to determine the contribution of each part of the artificial biofilm structure in order to further develop or redesign our initial solution for biofilm control. In order to carry out the construction of artificial biofilms using different bacteria, it is necessary to successfully attach the bacteria to the surface without reducing their viability.

Although there are many different strains of bacteria that can be used to manage and to control biofilm formation, many of them do not form biofilms and are thus not capable of attaching to many different materials. Furthermore, it has been demonstrated that many biotechnologically important bacterial strains may lose their intrinsic biofilm forming ability over time (TerAvest and Ajo-Franklin, 2016). In order to overcome this problem, it is necessary to implement new methods for cellular attachment that will promote the initial colonizers of the surface to stay attached and to form a biofilm. Bacteria must initially overcome very high repulsion forces from a surface (Hori and Matsumoto, 2010) and the conditions at the point of attachment must be favorable for growth. The surface must therefore be modified to promote initial attachment and to ensure the establishment of a relevant ecological niche, creating favorable conditions. After overcoming repulsion by decreasing the distance between the cell and the surface, it is expected that artificial attachment of bacterial cells will increase the likelihood of biofilm formation.

Our experience indicates that an approach that does not involve either genetic or chemical modification of the cell, is electrostatic modification of the surface, either of the material or the bacterial cell, using polyelectrolytes. However, highly charged PEs, especially those that are positively charged, have been used as antimicrobial coatings and prevented growth of bacteria due to their toxicity (Carmona-Ribeiro and De Melo Carrasco, 2013). Consequently, if PEs were chosen to be used for the attachment of live bacteria, either a selection of the appropriate combination of the PE and the bacterial strain must be made or the PE must be modified to mitigate its toxicity. The main goal of this study was thus to determine if the electrostatically modified cells of a selected strain, deposited onto the surface of a material could 
TABLE 1 | The growth conditions and biological characteristics of the selected bacterial strains. All selected candidates were chosen from both Gram + or Gram- groups in order to distinguish the contribution of the cell wall structure, shape and division time to the process of biofilm formation. Since polyethyleneimine (PEI) is known to be toxic for some bacteria, strains were divided depending on their resistance to PEl.

\begin{tabular}{|c|c|c|c|c|c|c|c|c|c|}
\hline № & Strain & Morphology & $\begin{array}{c}\text { Generation } \\
\text { time, } \\
\text { min }\end{array}$ & $\begin{array}{c}\text { Growth } \\
\text { temperature }\left({ }^{\circ} \mathrm{C}\right)\end{array}$ & $\begin{array}{c}\text { Biofilm } \\
\text { formation }\end{array}$ & $\begin{array}{l}\text { Consecutive } \\
\text { division } \\
\text { plan }\end{array}$ & $\begin{array}{c}\text { PEI } \\
\text { sensitivity }\end{array}$ & Characteristics & References \\
\hline 1 & $\begin{array}{l}\text { Staphylococcus } \\
\text { epidermidis DSM } \\
20044\end{array}$ & Cocci & 20 & 37 & $+++^{*}$ & Perpendicular & Sensitive & $\begin{array}{l}\text { Pathogen, isolated } \\
\text { from the human } \\
\text { nose }\end{array}$ & $\begin{array}{l}\text { Dice et al. } \\
\text { (2009), Saraiva } \\
\text { et al. (2020) }\end{array}$ \\
\hline 2 & $\begin{array}{l}\text { Staphylococcus } \\
\text { epidermidis } \mathrm{BH} 1\end{array}$ & Cocci & 100 & 37 & $-{ }^{* *}$ & Perpendicular & Sensitive & $\begin{array}{l}\text { Wild-type strain } \\
\text { isolated from } \\
\text { human skin }\end{array}$ & $\begin{array}{l}\text { Kurečič et al. } \\
\text { (2018), Saraiva } \\
\text { et al. (2020) }\end{array}$ \\
\hline 3 & $\begin{array}{l}\text { Bacillus subtilis } \\
\text { DSM } 5547\end{array}$ & Rod-shaped & 120 & 28 & $++{ }^{\star *}$ & Parallel & Sensitive & $\mathrm{n} / \mathrm{a}$ & $\begin{array}{l}\text { Burdett et al. } \\
\text { (1986) }\end{array}$ \\
\hline 4 & $\begin{array}{l}\text { Escherichia } \\
\text { coli DH5a }\end{array}$ & Rod-shaped & 30 & 37 & $-*$ & Parallel & Sensitive & $\begin{array}{l}\text { Sensitive to PEI, } \\
\text { unlike E. coli TOP10 }\end{array}$ & $\begin{array}{l}\text { Van Houdt et al. } \\
\text { (2004), Banning } \\
\text { et al. (2002) }\end{array}$ \\
\hline 5 & $\begin{array}{l}\text { Pseudomonas } \\
\text { putida DSM } 50198\end{array}$ & Rod-shaped & 20 & 28 & $++^{*}$ & Parallel & $\begin{array}{l}\text { Extremely } \\
\text { sensitive }\end{array}$ & $\mathrm{n} / \mathrm{a}$ & $\begin{array}{l}\text { Li et al. (2007); } \\
\text { Azoddein et al. } \\
\text { (2017) }\end{array}$ \\
\hline 6 & $\begin{array}{l}\text { Pseudomonas } \\
\text { fluorescens } \mathrm{CHAO}\end{array}$ & Rod-shaped & 33 & 28 & $+^{*}$ & Parallel & Resistant & $\begin{array}{l}\text { Produce acidic } \\
\text { extracellular } \\
\text { polysaccharides }\end{array}$ & $\begin{array}{l}\text { Bianciotto et al. } \\
\text { (2001); Humair } \\
\text { et al. (2009) }\end{array}$ \\
\hline 7 & $\begin{array}{l}\text { Escherichia coli } \\
\text { TOP10 }\end{array}$ & Rod-shaped & 30 & 37 & $-{ }^{*}$ & Parallel & $\begin{array}{l}\text { Highly } \\
\text { resistant }\end{array}$ & $\mathrm{n} / \mathrm{a}$ & $\begin{array}{l}\text { Cowan et al. } \\
\text { (2001), Stefan } \\
\text { et al. (2003) }\end{array}$ \\
\hline 8 & $\begin{array}{l}\text { Pseudomonas } \\
\text { stutzeri DSM } \\
10701\end{array}$ & Rod-shaped & 58 & 28 & $-{ }^{* *}$ & Parallel & $\begin{array}{l}\text { Extremely } \\
\text { sensitive }\end{array}$ & $\mathrm{n} / \mathrm{a}$ & $\begin{array}{l}\text { Bryan et al, } \\
\text { (1985) }\end{array}$ \\
\hline $9^{\dagger}$ & $\begin{array}{l}\text { Escherichia coli } \\
\text { TOP10 }\end{array}$ & Rod-shaped & 30 & 37 & $-^{*}$ & Parallel & $\begin{array}{l}\text { Highly } \\
\text { resistant }\end{array}$ & $\begin{array}{l}\text { Contains } \\
\text { fluorescent pRSET- } \\
\text { EmGFP vector }\end{array}$ & $\begin{array}{l}\text { Cowan et al. } \\
\text { (2001), Stefan } \\
\text { et al. (2003) }\end{array}$ \\
\hline $10^{\dagger}$ & Bacillus 25.2.M & Rod-shaped & $70^{* *}$ & 37 & $++{ }^{* *}$ & Parallel & $\mathrm{n} / \mathrm{a}$ & $\begin{array}{l}\text { Has an antimicrobial } \\
\text { activity }^{\star \star} \text { against } \\
\text { E. coli }\end{array}$ & $\begin{array}{l}\text { Zupančič et al. } \\
\text { (2018) }\end{array}$ \\
\hline
\end{tabular}

"+" and "-" indicate the ability and disability, respectively, to form biofilms based on data available in this study (**) or elsewhere (*). The sign " + " denotes bacteria used only to study the interaction of the artificial biofilm with potentially pathogenic bacteria.

prevent the attachment and the growth of another selected undesirable bacterial strain. To achieve this goal, we adopted three specific aims: 1) to reduce the toxicity of PEs and to develop a method for the electrostatic modification and deposition of different viable bacterial cells onto a material surface, 2) to determine whether the electrostatic attachment of bacteria increased the possibility of forming biofilms, and 3) to demonstrate the proof of concept that the electrostatically deposited cells composed of a potentially probiotic strain can prevent the formation of the biofilm by potentially pathogenic bacteria.

\section{MATERIALS AND METHODS}

\section{Bacterial Strains and Growth Conditions}

Different bacterial strains were used in experimental tests on the basis of their intrinsic physiological properties. As presented in Table 1, the strains were used to: 1) test the toxicity of the modified PEs, 2) observe the effect of PE deposition on the formation and stability of biofilms and 3) test the proof of concept of the protective nature of artificial biofilms against the potentially pathogenic bacterial strains. Bacterial strains were selected on a basis of different biological properties, including: 1) capability of formation of biofilms in the environment or in medical settings, 2) different shapes (e.g. bacillary Escherichia, Pseudomonas and Bacillus, and coccal Staphylococcus), 3) cell wall structure (Gram + and Gram -), and 4) differences in division time that contribute to the surface population. Since from our preliminary results the polyelectrolytes are known to be toxic for some bacteria, strains were differentiated according to their resistance to the polyelectrolytes, e.g. E. coli vs. P. stutzeri (see also Table 1).

Prior to experiments, the bacterial culture of each strain was pretreated by washing away the leftover components of the growth medium and obtaining comparable cell densities in the final suspension. The bacterial cell cultures were incubated overnight in a rotary shaker incubator (Multitron, Infors) at $150 \mathrm{rpm}$ and the optimal growth temperature (Table 1) in $50 \mathrm{ml}$ of Nutrient Broth 1 (NB1) medium (Carl Roth). The cells were washed 3 times with sterile $0.9 \% \mathrm{NaCl}$ solution using centrifugation at $5000 \mathrm{~g}$ for $5 \mathrm{~min}$. Before each experiment, the optical density of the cell suspension was normalized to optical density $(\mathrm{OD})_{600}=0.1$ (at the reduced optical path of the $200 \mu \mathrm{L}$ volume of a well of a 96 well microtiter plate; VWR). 


\section{Reduction of Polyethyleneimine Toxicity by Acetylation}

Since in our preliminary experiments PEI demonstrated toxicity when exposed to bacterial cells (see Supplementary Information SI, Supplementary Figure S1), here it was tested to see if reducing the number of amino groups in the PEI molecule would decrease its toxicity. However, PEI should retain a sufficiently positive charge to be capable of successful covering of bacterial cells. PEI was modified according to methods described by Forrest et al. (2004) to produce acetylated PEI (Ac-PEI). Briefly, acetic anhydride (Sigma-Aldrich) and acetic acid (Merck KGaA) were used to acetylate the branched $600-\mathrm{kDa}$ PEI (SigmaAldrich). The acetylation was carried out by mixing PEI with acetic anhydride $56 \%(\mathrm{w} / \mathrm{v})$ in the presence of acetic acid, followed by incubation at $60^{\circ} \mathrm{C}$ for $4 \mathrm{~h}$. The reaction solution was dialyzed using SnakeSkin ${ }^{\mathrm{TM}}$ Dialysis Tubing (10 K MWCO, $22 \mathrm{~mm}$, Thermo Fisher Scientific) for 2 days in distilled water. The $\mathrm{pH}$ was monitored regularly and water was changed every $2 \mathrm{~h}$ until neutral $\mathrm{pH}$ was reached. The dialysis volume was allowed to exceed the reaction volume by a factor of about 100 to facilitate purification of Ac-PEI from the reaction mixture. Finally, the concentration of Ac-PEI was adjusted to $2.5 \mathrm{mg} \mathrm{ml}^{-1}$ using milliQ water (MQ), the $\mathrm{pH}$ was adjusted to 7.0 using $1 \mathrm{M}$ $\mathrm{NaOH}$ or $\mathrm{HCl}$, and concentrations were chosen to prevent dilution of the polyelectrolyte solutions. The Ac-PEI solution was sterilized using $0.2 \mu \mathrm{m}$ pore size filters (Sartorius). The degree of acetylation of the purified polymer was determined directly by potentiometric measurements during the preliminary work and indirectly by measuring the electrophoretic mobility values of bacterial cells coated with polyelectrolytes with different levels of acetylation (see SI, Supplementary Table S1). The most important aspect after the acetylation procedure used in this experiment is the correlation of electrophoretic mobility values, acetylation procedure and viability of cells, since our aim was to attach viable cells electrostatically.

\section{Determination of the Suitability of the Ac-PEI for Surface Modification of Bacterial Cells}

Since a surface modified by PEs should enable electrostatic attachment of cells but should not be toxic to viable bacterial cells, toxicity tests of the native PEI and Ac-PEI were performed. It was also determined the efficiency of the reversal of the surface charge of the bacterial cells when either PEI or Ac-PEI were deposited onto the surface of cells, and the cells were coated by each type of the PE. Three strains that showed different levels of resistance against the native, non-acetylated PEI were selected (see Table 1). The strain E. coli TOP10 was resistant to PEI, while the other two strains, P. stutzeri DSM 100701 and P. putida DSM 50198, were sensitive to PEI. The toxicities of PEI and Ac-PEI were evaluated by measuring the growth rate and by Live/Dead staining.

The growth rate was determined by measuring the optical density $\left(\mathrm{OD}_{600}\right)$ during the incubation. Before incubation, the sterile solution of PEI was mixed (concentration $2.5 \mathrm{mg} \mathrm{ml}^{-1}$ ) with the sterile two-times more concentrated medium NB1 (2X $\mathrm{NB1})$ at a ratio of $1: 1(\mathrm{v} / \mathrm{v})$ in wells of a sterile microtiter plate (VWR). A total of $20 \mu \mathrm{L}$ of the bacterial cell suspension $\left(\mathrm{OD}_{600}=\right.$ 0.1 ) was added to each of the prepared dilutions. To determine bacterial growth for each well containing the Ac-PEI or PEI mixture $\mathrm{OD}_{600}$ was measured every $30 \mathrm{~min}$ during the $24 \mathrm{~h}$ incubation. During this period the cell suspension was incubated in the plate reader/incubator (Synergy H4, Biotek) at a growth temperature appropriate for each strain (see Table 1). A $30 \mathrm{~s}$ shaking period was applied before each measurement to resuspend the sedimented cells.

In the same three strains, the toxicity of the PEs was determined by the observations under microscope after Live/ Dead staining (Thermo Fisher Scientific) according to a commercially available procedure. In order to exclude possible effects from the interaction of $\mathrm{PE}$ with dye components rather than bacterial cells, it was also performed staining of the inanimate microcapsules of calcium carbonate coated with PEI or Ac-PEI according to the same protocol. Image acquisition was carried out using the inverted fluorescent microscope Zeiss Axio Observer Z1 (Zeiss, Germany), gfp ( $485 \mathrm{~nm} / 528 \mathrm{~nm}$ ) and dsRED filter sets $(599 \mathrm{~nm} / 619 \mathrm{~nm})$ and the digital CCD camera Orca (Hamamatsu, Japan).

Since acetylation reduces the number of charged amino groups in the PEI, the charge differences between native PEI and Ac-PEI were analyzed, by measuring the electrophoretic mobility using electrophoretic light scattering (ELS) measurements (Delsa Nano HC, Beckman Coulter) of the cells coated with a single layer of PE as described by Rybkin et al., 2019.

\section{The Electrostatic Deposition of Bacterial Cells and Biofilm Formation}

Monitoring of biofilm formation promoted by the electrostatic deposition of bacterial cells onto the surface of a coverslip glass (Menzel) in a growth chamber described by de Jong et al., 2011 and Rybkin et al., 2019, was accomplished with modifications. According to the coverslip characteristics the roughness of surface is estimated to be $19 \AA$. Coverslip glasses from the same producer were used in order to exclude the effects on bacterial attachment of surface properties such as roughness or hydrophobicity. Electrostatic deposition of cells was achieved by changing the surface charge of either the glass surface or the bacterial cells themselves.

In the first approach the glass surface was coated with either PEI or Ac-PEI. A total of $30 \mu \mathrm{L}$ of each PE (concentration $2.5 \mathrm{mg} \mathrm{ml}^{-1}$ ) in MQ was applied to one side of the glass by smearing the liquid across the glass surface using the edge of a cover slip. After the PE was evenly distributed in this way, the sample was allowed to dry at room temperature $(\mathrm{rt})\left(20^{\circ} \mathrm{C}\right)$. Subsequently, $20 \mu \mathrm{L}$ of the bacterial cell suspension $\left(\mathrm{OD}_{600}=\right.$ 0.1 ) was pipetted onto the glass surface and left to incubate for $15 \mathrm{~min}$ at rt. This droplet approach produced the highest success of cell attachment in the various bacteria that were tested. The droplet approach was selected after different approaches including dip coating, smearing and application of droplets were examined, in combination with varying temperatures 
$\left(+4^{\circ} \mathrm{C}\right.$ or $\left.+20^{\circ} \mathrm{C}\right), \mathrm{NaCl}$ concentrations, which were $0.154 \mathrm{M}$ or $0.015 \mathrm{M}$, and different incubation times of the cells, which were 5 , 15,30 or $45 \mathrm{~min}$.

In the second approach, $20 \mu \mathrm{L}$ of the suspension of the PEcoated cells was applied onto the unmodified glass surface within the prepared chamber and was allowed to incubate for $15 \mathrm{~min}$ at rt. Before executing the experiments, the unattached cells were in both cases washed off with $200 \mu \mathrm{L}$ of sterile $0.9 \% \mathrm{NaCl}$, the chamber was filled with standard NB1 medium and was finally sealed by the cover glass. In order to culture only the attached cells on the glass surface, the side of the chamber upon which the bacteria were deposited, was turned upside down, so that the surface with the attached cells was facing downwards. The images were taken at the same physical location on the surface after 0,3 , 24, and $48 \mathrm{~h}$. Recorded images were further processed in FIJI/ ImageJ software (Schindelin et al., 2012). After the initial deposition it was observed that the cells coated with the PE or deposited on the PE-coated glass tend to form aggregates when attached to the surface. Thus, the analyzed surface of one aggregate was considered as a single bacterial unit (see SI, Supplementary Figure S3). As a result, the surface area occupied by the bacterial cells was mainly used to estimate the dynamics of the biofilms.

\section{The Proof of Concept-Controlling Biofilm Development With the Artificial Biofilm}

Using the glass chambers described above, an artificial biofilm composed of Bacillus sp. strain 25.2. M was prepared. The strain used herein previously had been isolated from the oral cavity and was showing strong inhibition of growth of potentially pathogenic Gram-negative bacteria E. coli and Aggregatibacter actinomycetemcomitans, respectively (Zupančič et al., 2018). Viable cells of strain $25.2 \mathrm{M}$ were first stained with fluorescent dye Syto 64 (Thermo Fisher Scientific) by mixing the bacterial cell suspension $\left(\mathrm{OD}_{600}=1.0\right)$ with $10 \mu \mathrm{M}$ of Syto 64 fluorescent dye in ratio $1: 1(\mathrm{v} / \mathrm{v})$ and incubating the mixture in the dark for $30 \mathrm{~min}$. The cells were then washed 3 times by sterile $0.9 \% \mathrm{NaCl}$. Each time the cells were collected by centrifugation at 5,000 $\mathrm{g}$ for $5 \mathrm{~min}$ and finally, they were resuspended in sterile $0.9 \% \mathrm{NaCl}$. The artificial biofilm of Bacillus sp. 25.2. M was prepared by depositing a dense layer of cells of Bacillus sp. 25.2. M strain, Syto 64 stained and Ac-PEI coated on the glass surface. A total of $100 \mu \mathrm{L}$ of the bacterial cell suspension $\left(\mathrm{OD}_{600}=1.0\right)$, was incubated for $15 \mathrm{~min}$ at $\mathrm{rt}$ to allow the coated cells to attach to the glass surface. Using this protocol, it was managed to cover the surface with an average distance of $13.3 \pm 5.5 \mu \mathrm{m}$ between the bacterial cells.

To observe how the artificial biofilm of Bacillus sp. 25.2. M inhibits the attachment of Ac-PEI coated cells of a potentially pathogenic bacterium E. coli, it was used $20 \mu \mathrm{L}$ of the bacterial cell suspension $\left(\mathrm{OD}_{600}=0.05\right)$ of strain E. coli TOP10-emGFP (Emerald Green Fluorescent Protein, transformed by the expression vector pRSET-EmGFP; Thermo Fisher Scientific), which was spread over the surface of the artificial biofilm. In our experiment 100 times less E. coli than Bacillus sp. cells were used to simulate the initial colonization of the artificially formed biofilm. The chamber was filled with NB1 medium and tightly sealed as described previously. The chamber was incubated for $24 \mathrm{~h}$ without being turned upside down. A negative control for biofilm formation at the absence of Bacillus sp. 25.2. M based artificial biofilm and a positive control were prepared by constructing the artificial biofilm using cells of two strains of E. coli TOP10, one with and one without the plasmid. Bacterial cells without the plasmid were stained by Syto 64 (red) to contrast the cells of E. coli TOP10 - emGFP (green) applied onto the surface forming an artificial biofilm such as with the Bacillus sp.25.2.M. The cell growth and spatial distribution of E. coli TOP10 - emGFP on the surface were monitored at 0,6 and $24 \mathrm{~h}$ by fluorescent microscopy imaging using gfp $(485 \mathrm{~nm} / 528 \mathrm{~nm})$ for E. coli TOP10 - emGFP, and dsRED filter sets $(599 \mathrm{~nm} /$ $619 \mathrm{~nm}$ ), for the Bacillus sp. 25.2. M and E. coli TOP10 (plasmid free) strains stained by Syto 64 .

\section{Image Analysis}

In order to learn the growth dynamics of the biofilms, the shape, the size, the cell number and the gfp expression level as well as the extent of the surface covered with bacterial cells were determined from the obtained images, using the FIJI software (Schindelin et al., 2012). Only images with a contrast to noise ratio of $5.8 \pm 2.1$ were used for the analysis. Each stack of images was adjusted using the "subtract background" function with a rolling ball radius of 5 pixels and then was converted into a binary image using the "make binary" function. The boundaries of bacterial cells and their aggregates were outlined using the "find edges" algorithm (Burger and Burge, 2009) and this was followed by filling the inner area (Legland et al., 2016), using the "fill holes" function. The growth of biofilms was estimated by measuring the number and surface area of cells over time. Calculation of the surface area and number of bacterial cells was performed using the "analyze particles" plugin with the lowest size limit of $0.1 \mu \mathrm{m}^{2}$. The "mean gray" value parameter was used to evaluate the gfp (green fluorescent protein) expression level.

\section{Data Analysis}

Unless otherwise specified, data are always reported as mean \pm standard deviation calculated from three independent experimental measurements. Data sets were analyzed using the two tailed $t$-test. Statistical significance is represented as $\left({ }^{*}, \dagger\right)$ for $p$ value lower than 0.05 . Graph plotting was prepared and visualized using LibreOffice Calc (The Document Foundation), Inkscape (Free Software Foundation) and Fiji. Growth curves were analyzed in PMAnalyzer (Cuevas and Edwards, 2017).

\section{RESULTS}

\section{Toxicity of PEI Is Decreased by Acetylation}

In our preliminary experiments we observed that the toxicity of PEI varied between different bacterial strains (SI, Supplementary Figure S1). Using Live/Dead staining, PEI toxicity resulted in the death of $88 \pm 6 \%$ of the cells of Pseudomonas stutzeri, $87 \pm 7 \%$ of Pseudomonas putida and $55 \pm 4 \%$ of E. coli TOP 10 ( $\mathrm{n}=4$ for each bacterial species) (Figure 1). In control experiments, in which 

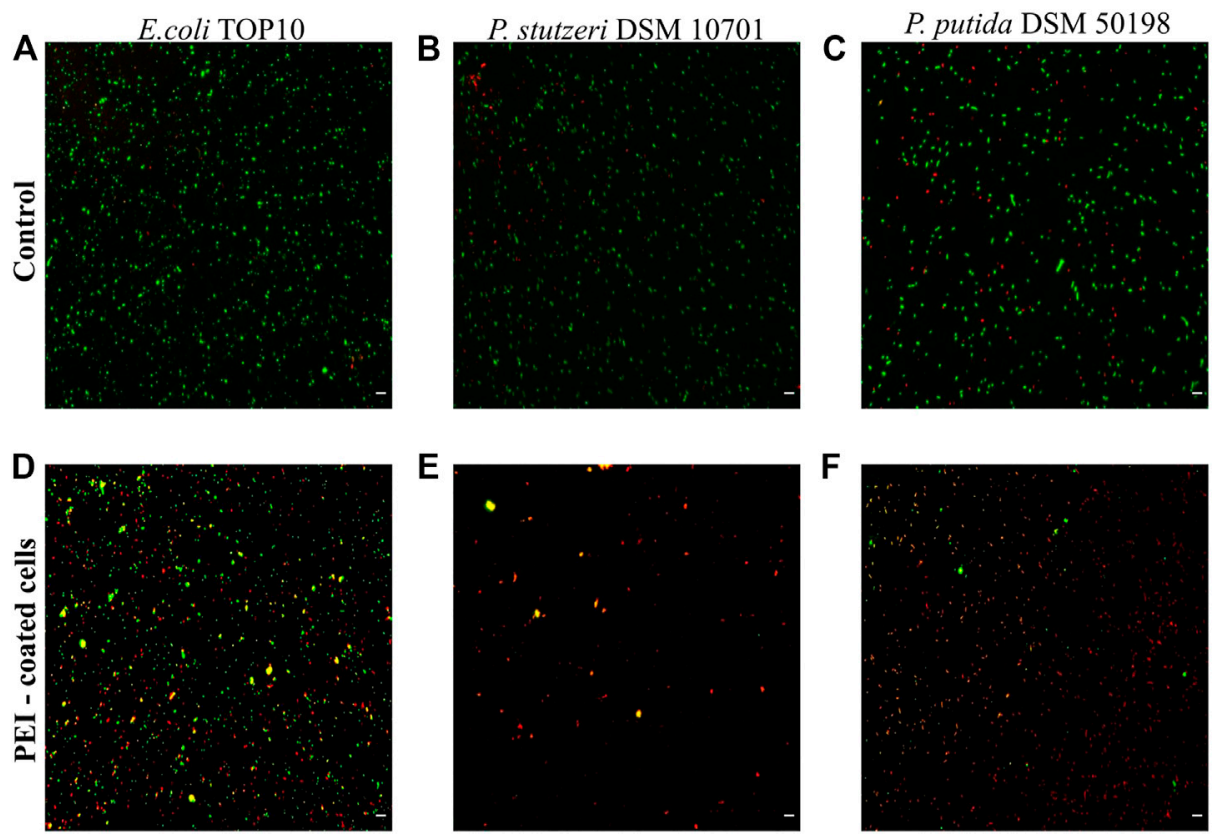

FIGURE 1 | Cell viability is reduced when cells are coated with PEl. The viability of E. coli TOP10, P. stutzeri DSM 10701 and P. putida DSM 50198 was characterized by Live/Dead staining when the surfaces of cells were not modified (controls, see A-C) and when the surfaces were coated by PEl (D-F). Viable cells are represented as green, dead cells as red and those giving signal in both channels as yellow. The latter were regarded as dead cells. Scale bar equals $10 \mu \mathrm{m}$.

TABLE 2 | The parameters of the growth curves obtained from MIC tests. Asymptote factor-biomass yield obtained during stationary phase. Growth level - amplitudeweighted metric quantifying the amount of growth of selected bacterial strains (Cuevas and Edwards, 2018). Growth class - qualitative classification of growth based on growth level $(+++g \geq 0.75 ;++0.5 \leq g<0.75 ;+0.35 \leq g<0.50 ;-0.25 \leq g<0.35 ;-g<0,25)$.

\begin{tabular}{|c|c|c|c|c|}
\hline Strain & Sample & Asymptote [OD] & Growth level [OD] & Growth class \\
\hline \multirow[t]{3}{*}{ S. epidermidis DSM 20044} & Control & $1.0 \pm 0.2$ & $1.5 \pm 0.4$ & +++ \\
\hline & PEI & $0.05 \pm 0.01^{\mathrm{ab}}$ & $0.04 \pm 0.02^{\mathrm{ab}}$ & -- \\
\hline & Acetylated PEI & $0.7 \pm 0.1$ & $0.7 \pm 0.2^{\mathrm{a}}$ & ++ \\
\hline & PEI & $0.23 \pm 0.004^{\mathrm{ab}}$ & $0.5 \pm 0.2^{\mathrm{ab}}$ & + \\
\hline & Acetylated PEI & $1.1 \pm 0.1$ & $1.2 \pm 0.1^{*}$ & +++ \\
\hline B. subtilis DSM 5547 & Control & $0.9 \pm 0.03$ & $1.1 \pm 0.03$ & +++ \\
\hline \multirow[t]{3}{*}{ P. putida DSM 50198} & Control & $0.9 \pm 0.1$ & $1.2 \pm 0.1$ & +++ \\
\hline & PEI & $0.1 \pm 0.01^{\mathrm{ab}}$ & $0.1 \pm 0.02^{\mathrm{ab}}$ & -- \\
\hline & Acetylated PEI & $1.1 \pm 0.03^{\mathrm{a}}$ & $0.95 \pm 0.03^{\mathrm{a}}$ & +++ \\
\hline \multirow[t]{3}{*}{ E. coli $\mathrm{DH} 5 \alpha$} & Control & $0.8 \pm 0.1$ & $1.1 \pm 0.1$ & +++ \\
\hline & PEI & $0.02 \pm 0.001^{\mathrm{ab}}$ & $0.01 \pm 0.003^{\mathrm{ab}}$ & -- \\
\hline & Acetylated PEI & $0.9 \pm 0.1$ & $1 \pm 0.15$ & +++ \\
\hline & Acetylated PEI & $1.0 \pm 0.02$ & $0.8 \pm 0.03$ & +++ \\
\hline \multirow[t]{3}{*}{ S. epidermidis $\mathrm{BH} 1$} & Control & $1.1 \pm 0.1$ & $1.6 \pm 0.1$ & +++ \\
\hline & PEI & $0.06 \pm 0.01^{\mathrm{ab}}$ & $0.05 \pm 0.01^{\mathrm{ab}}$ & -- \\
\hline & Acetylated PEI & $1.0 \pm 0.1^{\mathrm{a}}$ & $1.1 \pm 0.1^{\mathrm{a}}$ & +++ \\
\hline
\end{tabular}

${ }^{a}$ Significantly different than the control $(p<0.05)$.

${ }^{b}$ Significantly different than the acetylated PEI $(p<0.05)$. 

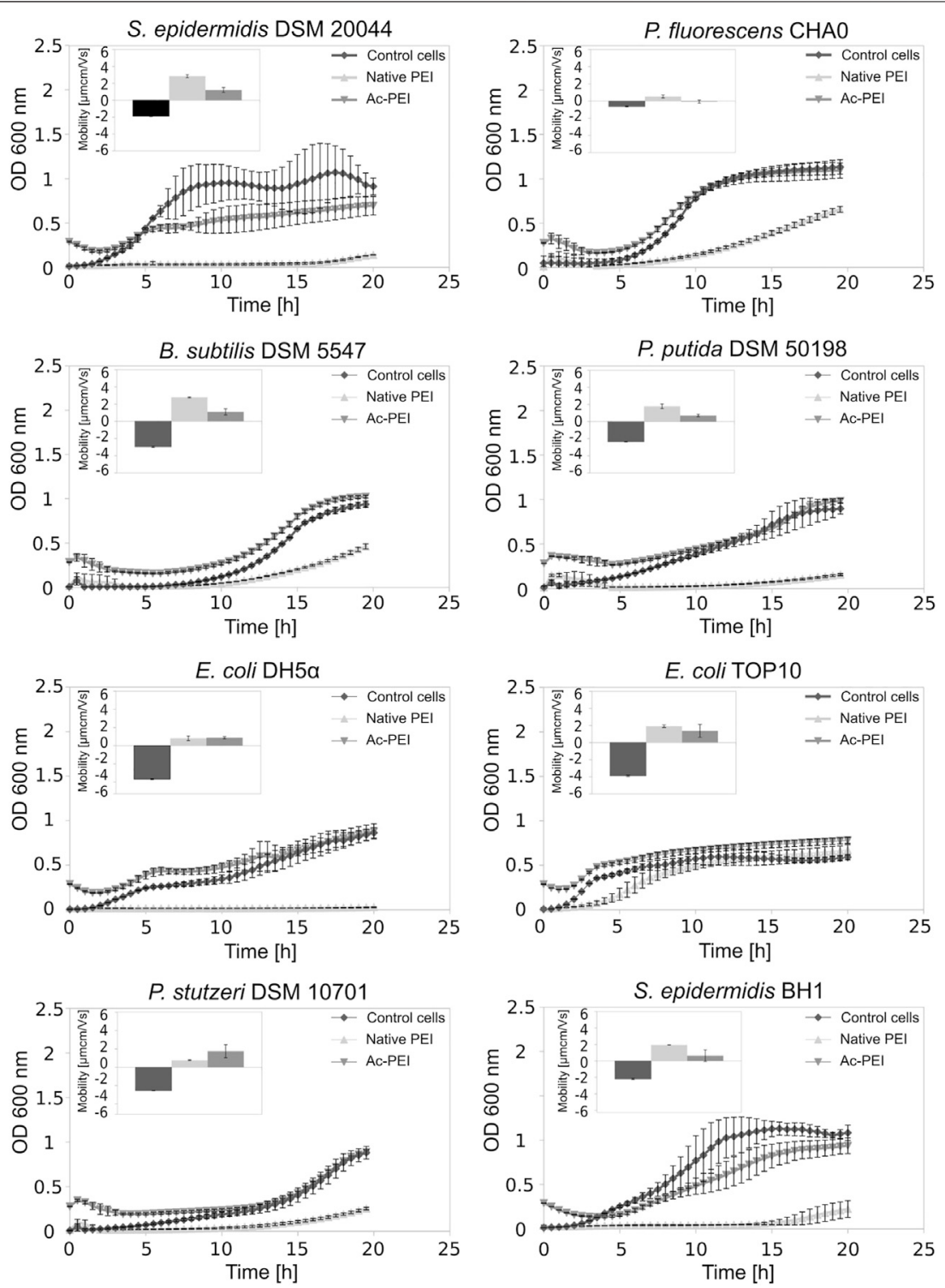

FIGURE 2|Acetylation of PEl reduces its toxicity. The growth curves of 8 different bacterial strains, both Gram+ and Gram-, are examined over a 25 h period in the presence of PEI $(\Delta)$ and Ac-PEI $(\nabla)$ or without the PE present (control) $(\bullet)$. Inserted graphs show electrophoretic mobilities.

PEI was absent, the number of dead cells was approximately $3-10$ times lower, $28 \pm 7 \%, 24 \pm 2 \%$ and $5 \pm 1 \%$, respectively. Both PE-coated and non-coated inanimate microcapsules propidium iodide did not interact with PEs (see SI, Supplementary Figure S2).

In our study, PEI inhibited the growth of all the tested strains within $24 \mathrm{~h}$, which was manifested by a prolonged lag phase of the cell cultures. The highest sensitivity to PEI exposure was observed for E. coli DH5a, S. epidermidis DSM 20044 and S. epidermidis BH1 (see Table 2) and the growth levels were reduced by factors of $178.33,36.93$, and 29.81 , respectively. On the contrary, E. coli TOP10 was found to be the most resistant to PEI toxicity and with this strain no reduction of the growth level was observed. The
PEI-coated cells of Gram-negative bacteria had values 2.06 times less on average than the electrophoretic mobilities of the Grampositive strains.

Using acetylation, the positive charge of the PEI molecules (see SI, Supplementary Table S1) was decreased. In contrast to PEI, Ac-PEI failed to inhibit the growth of all tested strains during the $25 \mathrm{~h}$ period (Figure 2; Table 2). In the presence of Ac-PEI all strains consistently showed higher values of the initial $\mathrm{OD}_{600}$ (Figure 2, see the first $5 \mathrm{~h}$ ) than in the control experiments. Acetylation of PEI decreased the electrophoretic mobility of the coated cells of the majority of strains, by a factor of 1.86 on average, except for E. coli DH5a and P. stutzeri, where the values were unchanged or even increased, by a factor of 2.29 . 

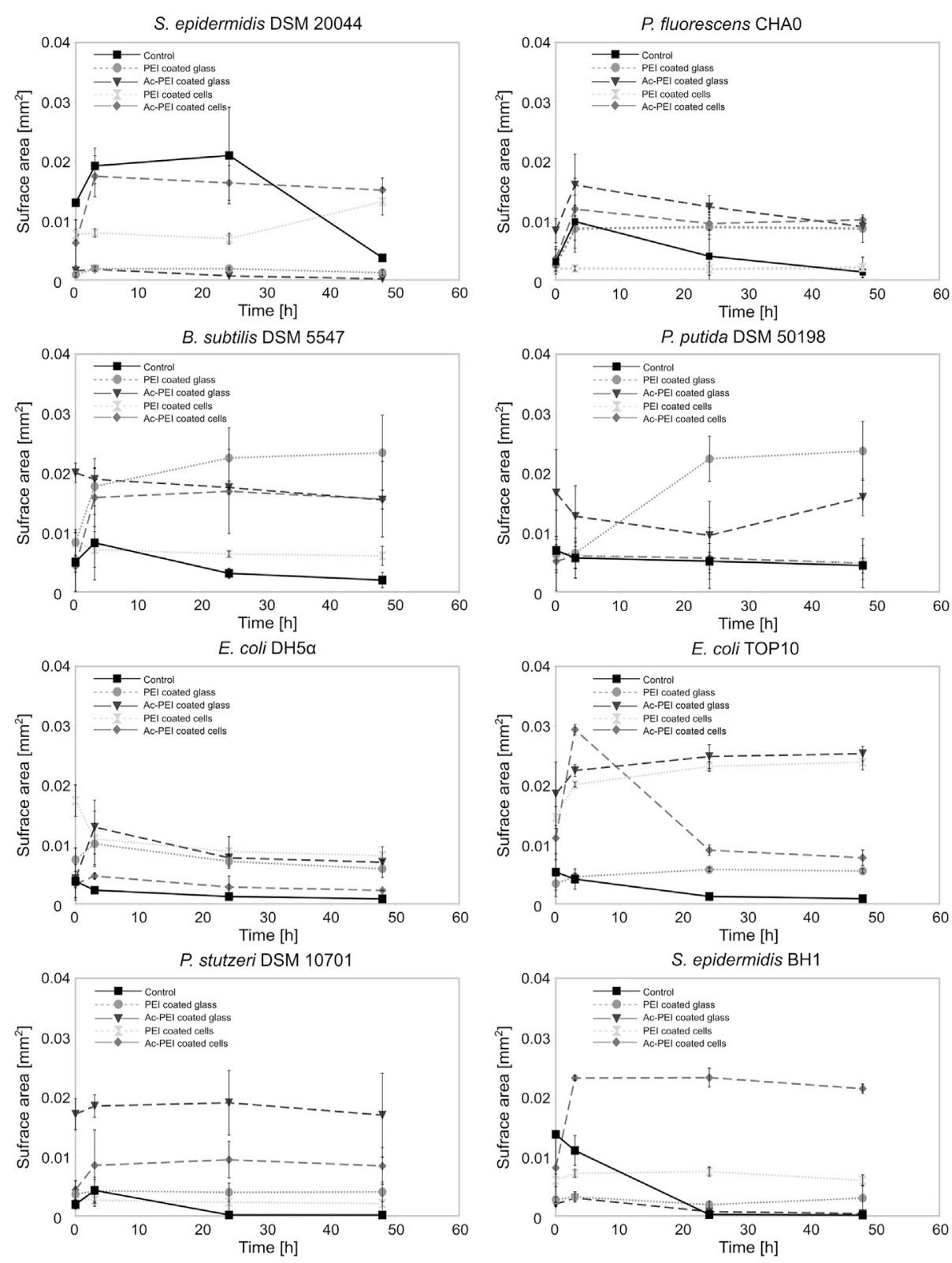

FIGURE 3 | The modification of the cellular surface charge or the charge of the material surface affects the number of cells that attach to the surface and the subsequent growth of the biofilm. The surface area covered by cells was examined for 8 different bacterial strains, biofilm forming or biofilm non-forming, over a $50 \mathrm{~h}$ period. The cells were coated by PEI $(\mathbf{X})$ or Ac-PEI $(\bullet)$ or deposited on the glass coated by PEl (O) or Ac-PEI ( $\mathbf{\nabla})$ or were not coated by the PE (control

\section{Electrostatically Attached Bacterial Cells can Form Biofilms}

Ac-PEI allowed us to manipulate the cell surface charge without its being toxic to the cells and it gave us possibility to determine how the electrostatic deposition of cells to the glass surface enabled both the biofilm forming and biofilm non-forming bacteria to occupy the freshly exposed surfaces (Figure 3).

After initial attachment, the surface area occupied by the majority of the control strains was reduced immediately after the initial stage $(0 \mathrm{~h})$ and was on average 28.76 times lower after
$48 \mathrm{~h}$. The non-modified cells of biofilm forming strains showed attachment patterns different from those of the biofilm nonforming strains. The biofilm non-forming strains did not show any significant increase in the surface area of the attached cells, while all three biofilm forming strains P. fluorescens CHA0, B. subtilis DSM 5547, and S. epidermidis DSM 20044 increased the surface area by a factor of 2.11 within the first $3 \mathrm{~h}$. Among the biofilm forming bacteria, the cells of S. epidermidis DSM 20044 covered the largest surface area at the $24 \mathrm{~h}$ time point, and was increased by a factor of $1.6(p<0.1)$ from the initial stage $(0 \mathrm{~h})$ and was on average 5.7 times larger than the other two biofilm 
TABLE 3 | Relative changes of the surface area of the attached biomass at $48 \mathrm{~h}$. Obtained values illustrate the increase or decrease of the surface area occupied by the bacteria, relatively to the initial stage $(0 \mathrm{~h})$. Values in bold represent the most appropriate approach for the attachment and biofilm formation of the bacteria onto the surface.

\begin{tabular}{|c|c|c|c|c|}
\hline Strain & PEI coated glass & Ac-PEI coated glass & PEI coated cells & Ac-PEI coated cells \\
\hline S. epidermidis DSM 20044 & $1.0 \pm 0.3$ & $0.2^{\mathrm{a}} \pm 0.2$ & $1.7^{\mathrm{a}} \pm 0.3$ & $2.9^{\mathrm{a}} \pm 1.0$ \\
\hline P. fluorescens $\mathrm{CHAO}$ & $2 . \mathbf{8}^{\mathrm{a}} \pm 1.3$ & $1.1 \pm 0.6$ & $1.2 \pm 1.0$ & $1.5 \pm 0.4$ \\
\hline B. subtilis DSM 5547 & $2.8^{\mathrm{a}} \pm 0.2$ & $0.8^{a} \pm 0.02$ & $0.7^{\mathrm{a}} \pm 0.1$ & $3.5^{a} \pm 0.6$ \\
\hline P. putida DSM 50198 & $4.3^{a} \pm 2.1$ & $0.8 \pm 0.3$ & $0.7 \pm 0.3$ & $0.7 \pm 0.3$ \\
\hline E. coli DH5a & $0.7^{a} \pm 0.04$ & $1.9 \pm 1.2$ & $0.3^{\mathrm{a}} \pm 0.3$ & $0.7^{a} \pm 0.1$ \\
\hline E. coli TOP10 & 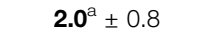 & $1.5^{\mathrm{a}} \pm 0.3$ & $\mathbf{1 . 7}^{\mathrm{a}} \pm 0.2$ & $0.5 \pm 0.4$ \\
\hline P. stutzeri DSM 10701 & $\mathbf{1 . 1 ^ { \mathrm { a } } \pm 0 . 1}$ & $0.8 \pm 0.3$ & $0.8 \pm 0.5$ & $\mathbf{2 . 1 ^ { a }} \pm 0.9$ \\
\hline S. epidermidis $\mathrm{BH} 1$ & $0.8^{a} \pm 0.4$ & $0.2^{a} \pm 0.1$ & $1.0 \pm 0.03$ & $2.4^{a} \pm 0.7$ \\
\hline
\end{tabular}

${ }^{a}$ Significantly different than at the initial stage $0 \mathrm{~h}(\mathrm{p}<0.05)$.

forming strains. The attachment S. epidermidis DSM 20044 survived past $3 \mathrm{~h}$, while the cells of other two biofilm forming strains gradually detached from the surface after $3 \mathrm{~h}$.

Among the electrostatic modifications tested, coating the glass with Ac-PEI produced the highest number of bacterial strains with increased initial attachment of cells. The four bacterial strains were E. coli TOP10, P. fluorescens CHA0, P. stutzeri DSM 10701, B. subtilis DSM 5547. None of the electrostatic modifications showed any improvements at $0 \mathrm{~h}$ for both the $S$. epidermidis strains. The modification of the surface of cells or glass by PEI or Ac-PEI deposition significantly prevented detachment of bacterial cells and sustained the artificial biofilm on the glass surface for up to $48 \mathrm{~h}$. Although the deposition of PEI on the glass surface as well as coating the bacterial cells with Ac-PEI were found not to be the most efficient for the initial attachment of cells, it sustained biofilm formation for up to $48 \mathrm{~h}$ for all strains except E. coli DH5 $\alpha$ (Table 3).

The glass surfaces coated with PEI supported artificial biofilm formation for 5 strains (Table 3; column PEI coated glass). Among these strains, the cells of P. putida DSM 50198 showed the highest increase of the surface area (on average 1.94 times more than other strains) occupied by cells over the $48 \mathrm{~h}$ period. In contrast, coating of the bacterial cells with Ac-PEI was the most suitable approach for 4 strains (see Table 3; column Ac-PEI coated cells), among which, B. subtilis DSM 5547 showed the highest increase, on average 2.15 times that of other strains of the occupied surface area at $48 \mathrm{~h}$. The other two approaches, coating the glass surface with Ac-PEI and coating the bacterial cells with PEI, were found to be less effective in keeping the bacterial cells attached, since only E. coli TOP10, and $S$. epidermidis DSM 20044 (only for Ac-PEI coated glass) showed a significant increase of the occupied surface area at the $48 \mathrm{~h}$ time point.

In contrast to the controls, in which almost all the cells of the biofilm forming bacteria were detached after $48 \mathrm{~h}$, surface modifications by PEs resulted in a 4.66 times larger occupied surface area, and the occupied surface areas were 26.02 times larger for the biofilm non-forming strains. Finally, the temporal dynamics of cellular attachment, the increase or decrease in the numbers of the attached cells were in both groups, biofilm forming and non-forming, similar due to the PE treated surfaces.

\section{Artificially Constructed Biofilm Inhibits growth of $E$. Coli on the Surface}

To test the effects of the artificial biofilm in an in vitro system containing two different bacterial species, it was successfully constructed the biofilm with Bacillus sp. 25.2. M, a potential oral probiotic strain, and E. coli. In the presence of the artificial biofilm the cell numbers of $E$. coli TOP10 - emGFP were constant over time and no significant growth was observed on the surface of the artificial biofilm during the $24 \mathrm{~h}$ exposure period (Figures 4A-C). Already at the initial stage, the Ac-PEI covered cells of E. coli did not attach well when applied to the surface of the Bacillus-based artificial biofilm and even though the attachment of $E$. coli was also low on the raw glass surface (negative control), there were 3.64 times fewer cells on the surface of the Bacillusbased biofilm compared to the negative control. The number of cells of E. coli TOP10 - emGFP, did not change during the $24 \mathrm{~h}$ test period, while the gfp signal (green) was significantly reduced, on average by a factor of 1.19 .

In the positive control (Figures 4D-F), where the cells of E. coli TOP10 were used instead of the strain Bacillus sp. 25.2. M to construct the artificial biofilm, it was observed a larger number of the attached cells in the initial stage, on average 18.46 times more than with the Bacillus-based biofilm and 5.1 times larger compared to the negative control. In the initial stage the number of attached cells in the positive control was higher compared to the negative control. But since the growth of E. coli TOP10 emGFP was significantly lower by 4.65 times on average, in the positive control during the $24 \mathrm{~h}$ period (Figures 4G-I), there was no significant difference between the positive and the negative control in the number of the attached cells after $24 \mathrm{~h}$. The gfp signal of E. coli - emGFP in the positive control was not changed over time, however it was already significantly lower at the initial stage (1.34) than in the negative control.

\section{DISCUSSION}

Our study clearly shows that the concept of using electrostatically deposited cells of Bacillus sp. 25.2. M, a potential probiotic strain, to construct an artificial biofilm controls further development of the biofilm by inhibition of E. coli growth (Figure 4). We need to 

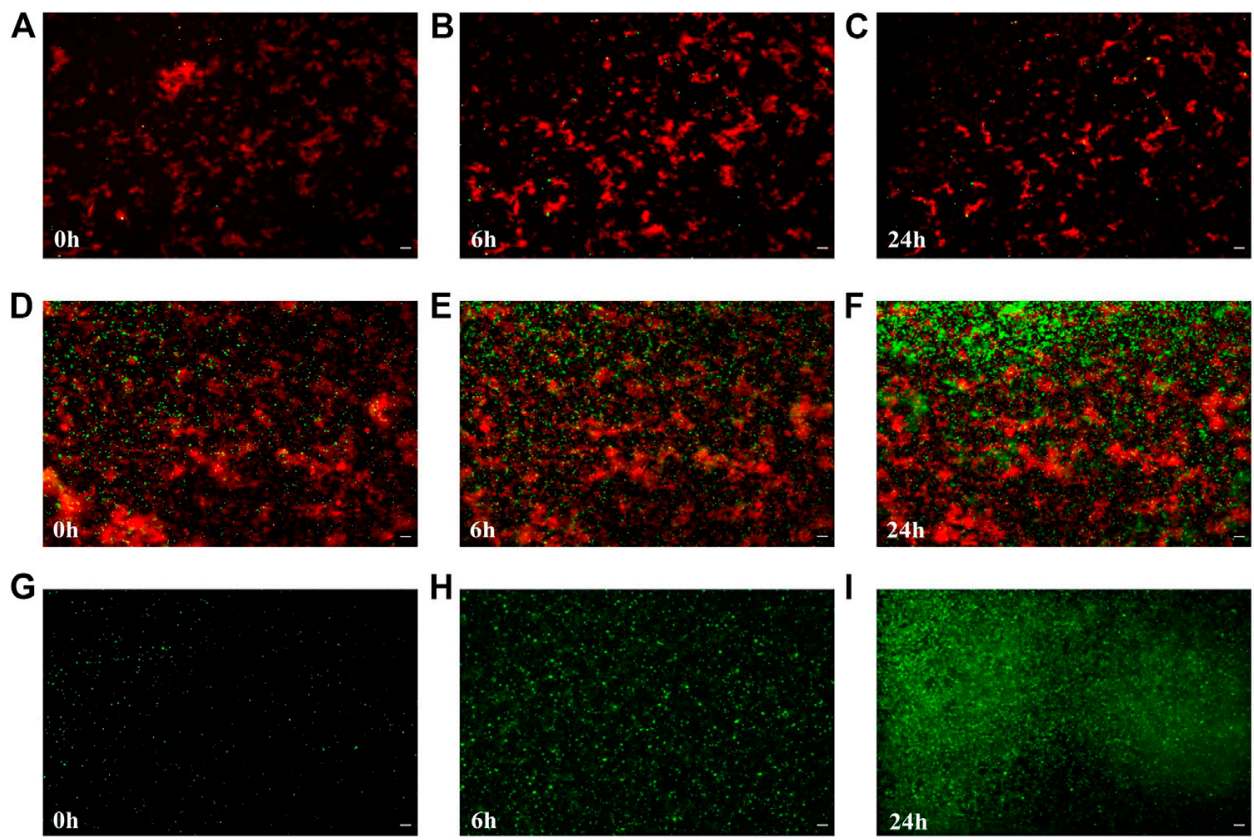

FIGURE 4 | The colonization and growth of potentially pathogenic E. coli is inhibited by the artificial biofilm made from the probiotic candidate strain Bacillus sp. 25.2.M. The number of attached cells of $E$. coli TOP10 emGFP, expressing the green fluorescent protein (gfp) (green), was determined after 0 , 6 and $24 \mathrm{~h}$ of cultivation when the artificial biofilm was made from the antimicrobial-producing Bacillus sp. 25.2. M (cells are stained by Syto 64; visible in red) being deposited onto the glass surface (A-C) or from E. coli TOP10 (red) not producing gfp (positive control) (D-F), or no pre-applied biofilm on the surface (negative control) (G-I). Scale bar equals $10 \mu \mathrm{m}$.

stress that the division rate of $E$. coli is 3 times higher at the experimental conditions used, meaning it could easily outgrow the film of Bacillus cells on the glass surface. Based on our previous study (Zupančič et al., 2018), we hypothesized that the bacterial cells that come into close contact with Bacillus sp. 25.2. $M$ are inhibited by its extracellular antimicrobial products. Many different Bacillus strains are known to produce a wide range of antimicrobial substances, such as biosurfactants (El-Sheshtawy et al., 2015), antibiotics (Stein, 2005), bacteriocin (Bizani and Brandelli, 2002), lipopeptides (Ongena and Jacques, 2008), and antimicrobial peptides (Jayaraman et al., 1999). Additionally, Bacillus could inhibit the growth of bacteria that attach to the surface by competitive exclusion, which is the result of highly specific niches that are created by Bacillus (La Ragione et al., 2001; Morikawa, 2006). Apart from the antimicrobial substances, the formation of a specific niche is a result of combined effects of the production of exopolymeric substances (EPS), changes of local $\mathrm{pH}$, oxygen depletion and exposure of incompatible receptors for attachment of other microbes (Xavier and Foster, 2007; Pham et al., 2009). Due to the production of spores Bacillus strains are also the most appropriate choice if the material surface is exposed to harsh environmental conditions. These strains can survive $\mathrm{pHs}$ up to 11 and temperatures as high as $80^{\circ} \mathrm{C}$ as well as high voltages during the electrospinning and other harsh conditions such as cold plasma treatment and pasteurization.

We reasoned that the highest efficiency of the biofilm for inhibiting the establishment and growth of harmful bacteria can be achieved when the surface of treated material is completely covered with beneficial cells, leaving the surface with no free binding sites for new colonizers. In our experiments it was observed that regardless of the method used for cell deposition only up to $21.37 \%$ of the surface was covered by the cells (Figure 3, B. subtilis deposited on the Ac-PEI coated glass), meaning that the predominately uncovered surface would allow harmful bacteria to establish microcolonies. For initial attachment to the raw surface, bacterial cells must be in close proximity to the surface, needing about 20-200 nm distance to experience the effect of Van der Waals forces and about $20 \mathrm{~nm}$ to initiate even stronger electrostatic interactions (Kumar and Anand, 1998; Palmer et al., 2007). It can be expected that due to the electrostatic repulsion between PE-modified bacterial cells during deposition to the surface, the cells can cover the surface only partially. To improve the binding events, the surface could be dried after deposition so that the Van der Waals forces become more prominent and the electrostatic interactions are reduced, but cell viability can be significantly lowered this way (Nocker et al., 2012). Thus, it is more appropriate to promote cell division after deposition of viable cells to achieve overgrowth of the surface, since our deposition approach promoted the formation of biofilms in both biofilm forming and nonforming bacteria. In our results the density of cells of biofilm non-forming E. coli TOP10 increased by a factor of 3.95 after such incubation (Figure 3, Ac-PEI coated cells of E. coli TOP10). We find that the first $3 \mathrm{~h}$ after deposition are the most critical in the formation of dense films, since after $3 \mathrm{~h}$ the state of biofilm 
density is probably the consequence of a dynamic equilibrium between detachment of bacteria and spreading of the biofilm over the surface. However, the timing of the formation of dense biofilms must be determined for each individual strain, especially if one aims to use bacteria with much longer generation times than those used in our study.

Since formation of dense biofilms is dependent on the process of cell division after the initial electrostatic attachment, it can be expected that the division plane of the bacteria could have an important role. If the division plane is perpendicular to the material surface, cells will divide and grow parallel to the material, staying very close to the surface, thus increasing the chance of keeping cells attached. In contrast, if bacterial cells divide in a plane parallel to the material surface, they tend to form columns or grape-like structures resulting in weakly attached biofilm and low occupation of the material surface. In our experiments two types of cells were used, with mixed parallel and perpendicular growth tendencies, coccoidal shaped cells of Staphylococcus strains, as well as those with only perpendicular division planes, rod shaped cells of bacteria like Bacillus (Saraiva et al., 2020; Bramkamp and van Baarle, 2009). For the former group where half of all the divisions happen in parallel to the surface and half perpendicularly, it can theoretically be expected that these bacteria spread over the surface with a two-time slower rate than those with perpendicular division plane. Unexpectedly, we observed that S. epidermidis DSM 20044 increased the occupied surface the most, up to 1.48 times within the first $3 \mathrm{~h}$ (Figure 3). This can be explained by the fact that bacillary cells can also grow over each other due to the formation of wrinkles in the biofilm, depending on the surface properties and cell density (DePas et al., 2013; Aguilar et al., 2018). Additionally, regardless of the spherically shaped cells dividing in different planes when the daughter cells are formed, they can occupy exposed empty space on the surface by settling at the most energetically favorable place, the oppositely charged surface of the material.

In our experiments it was also observed that for formation of dense biofilms it is more efficient to use a surface covered with PE than using the same PE to cover cells. According to Rybkin et al., 2019 it is expected that covering of cells with PE can increase the delay of the division and consequently slow down growth. In addition, the surface of the glass is still negatively charged when cells are released from the PE cover in contrast being present on the PE covered glass. Therefore, less bacterial cells produced after the replication can become attached to the non-covered glass surface (Figure 3). However, although the Ac-PEI coated cells were less efficient in the first few hours to form film than any of the PEI coated glass, the approach where cells were coated by AcPEI was the second-best approach just behind that using the PEI coated glass. This approach was the most efficient for the biofilm forming strains, which can be due to the electrostatic attachment of cells on the surface and placing of the whole process of biological attachment very close to the surface. In return, it increases the probability of attachment of the newly formed cells after the division although the PEs are not present either on the cell or on the glass surface. This is most obvious for all three strong biofilm forming strains since they can form biofilm without any assistance and it seems that the distance to the surface is one of the key factors for the formation of such biofilms (Palmer et al., 2007). Since here it was used the combined approach of physical attachment and biological biofilm formation, where attached cells must be alive and capable of cell division, the toxicity of PE must be considered. In this relation, different combinations of PE, either surface deposited or cell coated, must be tested for each particular strain (Figure 2; Table 2).

Currently, we could not determine why PEs were more toxic for one strain than for others, however, several factors have been reported that contribute to the PE toxicity. These include hydrophobicity, molecular size of PE (Qiao et al., 2012) or electrostatic interactions with the membrane molecules (Rawlinson et al., 2010), since the positively charged amino groups can form pores in the membrane (Brogden, 2005), and cause cell lysis (Fakhrullin et al., 2014). We also can not eliminate the possibility that PEs can alter the activity of proteins or interfere with metabolic processes, causing metabolic changes and cell death, since in our previous studies we observed the induction of production of constitutive protein by the PE entrapped E. coli cells (Rybkin et al., 2019). By simply comparing Gram-positive with Gram-negative bacteria, it can be expected that the architecture of the bacterial cell wall plays a key role in different outcomes when the bacteria are coated by PEs. With an outer membrane, less negatively charged lipids (Qiao et al., 2012), and the presence of lipopolysaccharide (LPS) making it harder for the PE to permeabilize the inner membrane, Gram-negative bacteria should be more resistant to surface modification by PEs than Gram-positive bacteria (Song et al., 2011; Thoma et al., 2014). Our study revealed the opposite (Figure 2 and Table 2, see Pseudomonas strains) because high PEI toxicity was also observed in Gram-negative strains. The resistant strains either have a lower amount of PE deposited on the cell surface or the PE molecules are spatially oriented differently, avoiding toxicity. Since toxicity was observed for the PE-modified cells with low or high electrophoretic mobilities and since the mobilities of the Ac-PEI surface modified cells (i.e. Ac-PEI is non-toxic) were similarly low for all strains, we concluded that the amount of the deposited PE is not the reason for the toxicity, but rather the interaction of the PE with the cell surface is responsible. Therefore, a detailed study of cell architecture either within one Gram type or between Gram types is thus necessary to better understand this interaction.

To lower the toxic effects of PEI, we used acetylation to derivatize the free primary amines and lower their level (Forrest et al., 2004) to an extent which would improve cell viability without seriously compromising the positive charge of the molecule. According to our prediction, the decrease in the charge density of the PEI caused by the primary amines decreased the binding efficiency of PEI and consequently its toxicity (Figure 2; Table 2). However, due to the higher survivability of cells, the Ac-PEI enables enough strong attachment inducing further biofilm formation. Besides modification of the polyelectrolytes, attachment of the bacteria on the surface can be improved by manipulating the surface parameters, including roughness, surface charge and hydrophobicity. Higher roughness should be more beneficial for the bacterial cells since they will 
have a larger area to which to attach, while combination of surface charge and hydrophobicity can improve binding of the polyelectrolytes with an inanimate surface.

In conclusion, we have demonstrated for the first time a new solution which does not prevent the inevitable establishment of the biofilm, but carefully manages its development by attachment of live bacteria. The electrostatic method is very useful since it enables artificial attachment of viable bacterial cells, including those unable to form a biofilm, by coating the cell surface with a positively charged non-toxic polyelectrolyte. The modification of PEs widens the repertoire of strains that can be used, and consequently the proposed approach can be applied to different surfaces in a variety of industries such as biotechnology, medical and other sectors, where prevention and control of biologically induced corrosion is important. The use of attached bacteria also prevents their detachment in the quick sand filter purification systems used for drinking and wastewater treatment and increases the success of bioaugmentation (Horemans et al., 2017).

\section{DATA AVAILABILITY STATEMENT}

The original contributions presented in the study are included in the article/Supplementary Material, further inquiries can be directed to the corresponding author.

\section{AUTHOR CONTRIBUTIONS}

DD executed the experimental part, partially performed statistical analysis and contributed partially to the writing. IR contributed to

\section{REFERENCES}

Aguilar, B., Ghaffarizadeh, A., Johnson, C. D., Podgorski, G. J., Shmulevich, I., and Flann, N. S. (2018). Cell Death as a Trigger for Morphogenesis. PLoS One 13 (3), e0191089. doi:10.1371/journal.pone.0191089

Alberte, R. S., Snyder, S., Zahuranec, B. J., and Whetstone, M (1992). Biofouling Research Needs for the United States Navy: Program History and Goals. Biofouling 6 (2), 91-95. doi:10.1080/ 08927019209386214

Azoddein, Abd. A. M., Ahmad, M. M., Yunus, R. M., and Sulaiman, N. M. N. (2017). Effect of Acclimatization Time to Microbial Cell Growth and Biosynthesis of Mesophilic Gammaproteobacterium, in Orbital Shake Flasks. EDP Sciences 109, 04003. doi:10.1051/matecconf/201710904003

Bianciotto, V., Andreotti, S., Balestrini, R., Bonfante, P., and Perotto, S. (2001). Mucoid Mutants of the Biocontrol Strain Pseudomonas Fluorescens CHA0 Show Increased Ability in Biofilm Formation on Mycorrhizal and Nonmycorrhizal Carrot Roots. Mpmi 14 (2), 255-260. doi:10.1094/mpmi. 2001.14.2.255

Bizani, D., and Brandelli, A. (2002). Characterization of a Bacteriocin Produced by a Newly Isolated Bacillus Sp. Strain 8 A. J. Appl. Microbiol. 93 (3), 512-519. doi:10.1046/j.1365-2672.2002.01720.x

Bouckaert, J., Berglund, J., Schembri, M., De Genst, E., Cools, L., Wuhrer, M., et al. (2005). Receptor Binding Studies Disclose a Novel Class of High-Affinity Inhibitors of the Escherichia coli FimH Adhesin. Mol. Microbiol. 55 (2), 441-455. doi:10.1111/j.1365-2958.2004.04415.x

Bradshaw, D. J., Marsh, P. D., Watson, G. K., and Allison, C. (1998). Role of Fusobacterium Nucleatum and Coaggregation in Anaerobe Survival in the design of the experiments, partially performed statistical analysis, partially contributed to the writing and executed the experimental part. TR was involved in the design of the experiments, contributed to the writing and critical reading of the manuscript. AL developed the idea and concept, designed and executed the experiments, and prepared the manuscript.

\section{FUNDING}

Work was supported by Slovenian-Russian bilateral project (BI-RU/16-18-039), covering partially travel expenses, Slovenian national projects (J4-7640, J1-6746, J3-1762, J19194, J7-9400, and P1-0143) for buying consumables, Flemish-Slovenian research project: Bioavailable mercury methylation in the Adriatic sea (BE MERMAiD, grant agreement N1-0100)-for partial getting bacterial strains, Helmholtz Association (grant PIE-0007 CROSSING)-for operational costs, European Urban Initiative Actions founded project Applause (Grant agreement UIA02-228)-for operational costs, 2019 - 2023 (EU - Horizon 2020): InteGRated systems for Effective ENvironmEntal Remediation (GREENER, grant agreement 826312)-for partial getting bacterial strains and European Commission (SurfBio project, grant no.: 952379)-for operational costs.

\section{SUPPLEMENTARY MATERIAL}

The Supplementary Material for this article can be found online at: https://www.frontiersin.org/articles/10.3389/fmats.2021.624631/ full\#supplementary-material

Planktonic and Biofilm Oral Microbial Communities during Aeration. Infect. Immun. 66 (10), 4729-4732. doi:10.1128/iai.66.10.4729-4732.1998

Bramkamp, M., and van Baarle, S. (2009). Division Site Selection in Rod-Shaped Bacteria. Curr. Opin. Microbiol. 12 (6), 683-688. doi:10.1016/j.mib.2009.10.002

Brogden, K. A. (2005). Antimicrobial Peptides: Pore Formers or Metabolic Inhibitors in Bacteria? Nat. Rev. Microbiol. 3 (3), 238-250. doi:10.1038/ nrmicro1098

Brooks, W., Demuth, D. R., Gil, S., and Lamont, R. J. (1997). Identification of a Streptococcus Gordonii SspB Domain that Mediates Adhesion to Porphyromonas Gingivalis. Infect. Immun. 65 (9), 3753-3758. doi:10.1128/ iai.65.9.3753-3758.1997

Bryan, B. A., Jeter, R. M., and Carlson, C. A. (1985). Inability of Pseudomonas Stutzeri Denitrification Mutants with the Phenotype of Pseudomonas Aeruginosa to Grow in Nitrous Oxide. Appl. Environ. Microbiol. 50 (5), 1301-1303. doi:10.1128/aem.50.5.1301-1303.1985

Bucci, V., Nadell, C. D., and Xavier, J. B. (2011). The Evolution of Bacteriocin Production in Bacterial Biofilms. The Am. Naturalist 178 (6), E162-E173. doi:10.1086/662668

Burdett, I. D., Kirkwood, T. B., and Whalley, J. B. (1986). Growth Kinetics of Individual Bacillus Subtilis Cells and Correlation with Nucleoid Extension. J. Bacteriol. 167 (1), 219-230. doi:10.1128/jb.167.1.219-230.1986

Burger, W., and Burge, M. J. (2009). Digital Image Processing: An Algorithmic Introduction Using Java. Berlin, Germany: Springer Science \& Business Media.

Carmona-Ribeiro, A.M., and de Melo Carrasco, L. D. (2013). Cationic Antimicrobial Polymers and Their Assemblies. Int. J. Mol. Sci. 14 (5), 9906-9946. doi:10.3390/ijms14059906

Chaali, M., Naghdi, M., Brar, S. K., and Avalos-Ramirez, A. (2018). A Review on the Advances in Nitrifying Biofilm Reactors and Their Removal Rates in 
Wastewater Treatment. J. Chem. Technol. Biotechnol. 93 (11), 3113-3124. doi:10.1002/jctb.5692

Banning, N., Toze, S., and Mee, B. J. (2002). Escherichia coli Survival in Groundwater and Effluent Measured Using a Combination of Propidium Iodide and the Green Fluorescent Protein. J. Appl. Microbiol. 93 (1), 69-76. doi:10.1046/j.1365-2672.2002.01670.x

Cheng, K.-C., Demirci, A., Catchmark, J. M., and Catchmark (2010). Advances in Biofilm Reactors for Production of Value-Added Products. Appl. Microbiol. Biotechnol. 87 (2), 445-456. doi:10.1007/s00253-010-2622-3

Cowan, S. E., Liepmann, D., and Keasling, J. D. (2001). Development of Engineered Biofilms on Poly-L-Lysine Patterned Surfaces. Biotechnol. Lett. 23 (15), 1235-1241. doi:10.1023/a:1010581503842

Cuevas, D. A., and Edwards, R. A. (2017). PMAnalyzer: A New Web Interface for Bacterial Growth Curve Analysis. Bioinformatics 33 (12), 1905-1906. doi:10. 1093/bioinformatics/btx084

Cuevas, D. A., and Edwards, R. A. (2018). Growth Score: A Single Metric to Define Growth in 96-Well Phenotype Assays. PeerJ 6, e4681. doi:10.7717/peerj.4681

de Jong, I. G., Beilharz, K., Kuipers, O. P., and Veening, J -W. (2011). Live Cell Imaging of Bacillus Subtilis and Streptococcus Pneumoniae Using Automated Time-Lapse Microscopy. JoVE (Journal of Visualized Experiments) 28 (53), 3145. doi: $10.3791 / 3145$

DePas, W. H., Hufnagel, D. A., Lee, J. S., Blanco, L. P., Bernstein, H. C., Fisher, S. T., et al. (2013). Iron Induces Bimodal Population Development by Escherichia Coli. Proc. Natl. Acad. Sci. 110 (7), 2629-2634. doi:10.1073/pnas.1218703110

Dexter, S. C., Sullivan, J. D., Williams, J., and Watson, S. W. (1975). Influence of Substrate Wettability on the Attachment of Marine Bacteria to Various Surfaces1. Appl. Microbiol. 30 (2), 298-308. doi:10.1128/am.30.2.298-308.1975

Dice, B., Stoodley, P., Buchinsky, F., Metha, N., Ehrlich, G. D., Hu, F. Z., et al. (2009). Biofilm Formation Byica-Positive Andica-Negative Strains ofStaphylococcus Epidermidis In Vitro. Biofouling 25 (4), 367-375. doi:10. 1080/08927010902803297

El-Sheshtawy, H. S., Aiad, I., Osman, M. E., Abo-ELnasr, A. A., and Kobisy, A. S. (2015). Production of Biosurfactant from Bacillus Licheniformis for Microbial Enhanced Oil Recovery and Inhibition the Growth of Sulfate Reducing Bacteria. Egypt. J. Pet. 24 (2), 155-162. doi:10.1016/j.ejpe.2015.05.005

Fakhrullin, R., Choi, I., and Lvov, Y. (2014). Cell Surface Engineering: Fabrication of Functional Nanoshells. Washington DC, WA: Royal Society of Chemistry.

Forrest, M. L., Meister, G. E., Koerber, J. T., and Pack, D. W. (2004). Partial Acetylation of Polyethylenimine Enhances In Vitro Gene Delivery. Pharm. Res. 21 (2), 365-371. doi:10.1023/b:pham.0000016251.42392.1e

Ghiasian, M. (2020). "Chapter 9 - Microbial Biofilms: Beneficial Applications for Sustainable Agriculture," in In New And Future Developments In Microbial Biotechnology And Bioengineering, Editors A. A. Rastegari, A. N. Yadav, and N. Yadav (Amsterdam, Netherlands: Elsevier). 145-55. doi:10.1016/B978-0-12820526-6.00009-9

Horemans, B., Raes, B., Vandermaesen, J., Simanjuntak, Y., Brocatus, H., T'Syen, J., et al. (2017). Biocarriers Improve Bioaugmentation Efficiency of a Rapid Sand Filter for the Treatment of 2,6-Dichlorobenzamide-Contaminated Drinking Water. Environ. Sci. Technol. 51 (3), 1616-1625. doi:10.1021/acs.est.6b05027

Hori, K., and Matsumoto, S. (2010). Bacterial Adhesion: From Mechanism to Control. Biochem. Eng. J. 48 (3), 424-434. doi:10.1016/j.bej.2009.11.014

Humair, B., González, N., Mossialos, D., Reimmann, C., and Haas, D. (2009). Temperature-Responsive Sensing Regulates Biocontrol Factor Expression in Pseudomonas Fluorescens CHA0. Isme J. 3 (8), 955-965. doi:10.1038/ismej. 2009.42

Jakubovics, N. S. (2015). Intermicrobial Interactions as a Driver for Community Composition and Stratification of Oral Biofilms. J. Mol. Biol. 427 (23), 3662-3675. doi:10.1016/j.jmb.2015.09.022

Jayaraman, A., Mansfeld, F. B., and Wood, T. K. (1999). Inhibiting SulfateReducing Bacteria in Biofilms by Expressing the Antimicrobial Peptides Indolicidin and Bactenecin. J. Ind. Microbiol. Biotechnol. 22 (3), 167-175. doi:10.1038/sj.jim.2900627

Kumar, C. G., and Anand, S. K. (1998). Significance of Microbial Biofilms in Food Industry: A Review. Int. J. Food Microbiol. 42 (1-2), 9-27. doi:10.1016/s01681605(98)00060-9

Kurečič, M., Rijavec, T., Hribernik, S., Lapanje, A., Kleinschek, K. S., and Maver, U. (2018). Novel Electrospun Fibers with Incorporated Commensal Bacteria for
Potential Preventive Treatment of the Diabetic Foot. Nanomedicine (Lond) 13 (13), 1583-1594. doi:10.2217/nnm-2018-0014

La Ragione, R., Roberto, M., Casula, G., Cutting, S. M., and Woodward, M. J. (2001). Bacillus Subtilis Spores Competitively Exclude Escherichia Coli O78: K80 in Poultry. Vet. Microbiol. 79 (2), 133-142. doi:10.1016/s0378-1135(00) 00350-3

Legland, D., Arganda-Carreras, I., and Andrey, P. (2016). MorphoLibJ: Integrated Library and Plugins for Mathematical Morphology with ImageJ. Bioinformatics 32 (22), 3532-3534. doi:10.1093/bioinformatics/btw413

Li, X. Z., Hauer, B., and Rosche, B. (2007). Single-Species Microbial Biofilm Screening for Industrial Applications. Appl. Microbiol. Biotechnol. 76 (6), 1255-1262. doi:10.1007/s00253-007-1108-4

Linklater, D. P., Baulin, V. A., Juodkazis, S., Russell, J., Paul, S., and Ivanova, E. P. (2020). Mechano-Bactericidal Actions of Nanostructured Surfaces. Nat. Rev. Microbiol., 1-15. doi:10.1038/s41579-020-0414-z

Liu, W., Russel, J., Røder, H. L., Madsen, J. S., Burmølle, M., and Sørensen, S. J. (2017). Low-abundant Species Facilitates Specific Spatial Organization that Promotes Multispecies Biofilm Formation. Environ. Microbiol. 19 (7), 2893-2905. doi:10.1111/1462-2920.13816

Lorenzetti, M., Dogša, I., Stošicki, T., Stopar, D., Kalin, M., Kobe, S., et al. (2015). The Influence of Surface Modification on Bacterial Adhesion to TitaniumBased Substrates. ACS Appl. Mater. Inter. 7 (3), 1644-1651. doi:10.1021/ am507148n

Marsh, P. D., Moter, A., and Devine, D. A. (2011). Dental Plaque Biofilms: Communities, Conflict and Control. Periodontol. 55 (1), 16-35. doi:10.1111/ j.1600-0757.2009.00339.x

Morikawa, M. (2006). Beneficial Biofilm Formation by Industrial Bacteria Bacillus Subtilis and Related Species. J. Biosci. Bioeng. 101 (1), 1-8. doi:10.1263/jbb. 101.1

Nocker, A., Fernández, P. S., Montijn, R., and Schuren, F. (2012). Effect of Air Drying on Bacterial Viability: A Multiparameter Viability Assessment. J. Microbiol. Methods 90 (2), 86-95. doi:10.1016/j.mimet.2012.04.015

O’May, G. A., Jacobsen, S. M., Stickler, D. J., Mobley, H. L. T., and Shirtliff, M. E. (2008). Complicated Urinary Tract Infections Due to Catheters. Berlin, Germany: Springer.

Oliveira, G. S., Lopes, D. R. G., Andre, C., Silva, C. C., Baglinière, F., and Vanetti, M. C. D. (2019). Multispecies Biofilm Formation by the Contaminating Microbiota in Raw Milk. Biofouling 35 (8), 819-831. doi:10.1080/08927014.2019.1666267

Ongena, M., and Jacques, P. (2008). Bacillus Lipopeptides: Versatile Weapons for Plant Disease Biocontrol. Trends Microbiol. 16 (3), 115-125. doi:10.1016/j.tim. 2007.12.009

Palmer, J., Flint, S., and Brooks, J. (2007). Bacterial Cell Attachment, the Beginning of a Biofilm. J. Ind. Microbiol. Biotechnol. 34 (9), 577-588. doi:10.1007/s10295007-0234-4

Pham, L. C., van Spanning, R. J., Röling, W. F., Prosperi, A. C., Terefework, Z., ten Cate, J. M., et al. (2009). Effects of Probiotic Lactobacillus Salivarius W24 on the Compositional Stability of Oral Microbial Communities. Arch. Oral Biol. 54 (2), 132-137. doi:10.1016/j.archoralbio.2008.09.007

Qiao, Y., Yang, C., Coady, D. J., Ong, Z. Y., Hedrick, J. L., and Yang, Y.-Y. (2012). Highly Dynamic Biodegradable Micelles Capable of Lysing Gram-Positive and Gram-Negative Bacterial Membrane. Biomaterials 33 (4), 1146-1153. doi:10. 1016/j.biomaterials.2011.10.020

Rawlinson, L.-A., Ryan, S. M., Mantovani, G., Syrett, J. A., Haddleton, D. M., and Brayden, D. J. (2010). Antibacterial Effects of Poly(2-(dimethylamino Ethyl) methacrylate) against Selected Gram-Positive and Gram-Negative Bacteria. Biomacromolecules 11 (2), 443-453. doi:10.1021/bm901166y

Rijavec, T., Zrimec, J., Spanning, R., and Lapanje, A. (2019). Natural Microbial Communities Can Be Manipulated by Artificially Constructed Biofilms. Adv. Sci. 6 (22), 1901408. doi:10.1002/advs.201901408

Rybkin, I., Gorin, D., Sukhorukov, G., and Lapanje, A. (2019). Thickness of Polyelectrolyte Layers of Separately Confined Bacteria Alters Key Physiological Parameters on a Single Cell Level. Front. Bioeng. Biotechnol. 7, 378. doi:10.3389/fbioe.2019.00378

Saraiva, B. M., Sorg, M., Pereira, A. R., Ferreira, M. J., Caulat, L. C., Reichmann, N. T., et al. (2020). Reassessment of the Distinctive Geometry of Staphylococcus Aureus Cell Division. Nat. Commun. 11 (1), 1-7. doi:10.1038/s41467-020$17940-9$ 
Schindelin, J., Arganda-Carreras, I., Frise, E., Kaynig, V., Longair, M., Pietzsch, T., et al. (2012). Fiji: An Open-Source Platform for Biological-Image Analysis. Nat. Methods 9 (7), 676-682. doi:10.1038/nmeth.2019

Schneider, R. P. (1997). Bacterial Adhesion to Solid Substrata Coated with Conditioning Films Derived from Chemical Fractions of Natural Waters. J. Adhes. Sci. Technol. 11 (7), 979-994. doi:10.1163/156856197x00543

Song, A., Walker, S. G., Parker, K. A., and Sampson, N. S. (2011). Antibacterial Studies of Cationic Polymers with Alternating, Random, and Uniform Backbones. ACS Chem. Biol. 6 (6), 590-599. doi:10.1021/cb100413w

Stadler, R., Wei, L., Fürbeth, W., Grooters, M., and Kuklinski, A. (2010). Influence of Bacterial Exopolymers on Cell Adhesion of Desulfovibrio Vulgaris on High Alloyed Steel: Corrosion Inhibition by Extracellular Polymeric Substances (EPS). Mater. Corrosion 61 (12), 1008-1016. doi:10.1002/maco.201005819

Stefan, A., Reggiani, L., Cianchetta, S., Radeghieri, A., Rodriguez, A. G. V. Y, and Hochkoeppler, A. (2003). Silencing of the Gene Coding for the $\epsilon$ Subunit of DNA Polymerase III Slows Down the Growth Rate ofEscherichia Colipopulations. FEBS Lett. 546 (2-3), 295-299. doi:10.1016/s0014-5793(03) 00604-5

Stein, T. (2005). Bacillus Subtilis Antibiotics: Structures, Syntheses and Specific Functions. Mol. Microbiol. 56 (4), 845-857. doi:10.1111/j.1365-2958.2005. 04587.x

TerAvest, M. A., and Ajo-Franklin, C. M. (2016). Transforming Exoelectrogens for Biotechnology Using Synthetic Biology. Biotechnol. Bioeng. 113 (4), 687-697. doi:10.1002/bit.25723

Thoma, L. M., Boles, B. R., and Kuroda, K. (2014). Cationic Methacrylate Polymers as Topical Antimicrobial Agents againstStaphylococcus aureusNasal Colonization. Biomacromolecules 15 (8), 2933-2943. doi:10.1021/bm500557d

Upritchard, H. G., Yang, J., Bremer, P. J., Lamont, I. L., and McQuillan, A. J. (2007). Adsorption to Metal Oxides of thePseudomonasaeruginosaSiderophore
Pyoverdine and Implications for Bacterial Biofilm Formation on Metals. Langmuir 23 (13), 7189-7195. doi:10.1021/la7004024

Van Houdt, R., Aertsen, A., Jansen, A., Quintana, A. L., and Michiels, C. W. (2004). Biofilm Formation and Cell-To-Cell Signalling in Gram-Negative Bacteria Isolated from a Food Processing Environment. J. Appl. Microbiol. 96 (1), 177-184. doi:10.1046/j.1365-2672.2003.02131.x

Vigneron, A., Head, I. M., and Tsesmetzis, N. (2018). Damage to Offshore Production Facilities by Corrosive Microbial Biofilms. Appl. Microbiol. Biotechnol. 102 (6), 2525-2533. doi:10.1007/s00253-018-8808-9

Xavier, J. B., and Foster, K. R. (2007). Cooperation and Conflict in Microbial Biofilms. Pnas 104 (3), 876-881. doi:10.1073/pnas.0607651104

Zuo, R. (2007). Biofilms: Strategies for Metal Corrosion Inhibition Employing Microorganisms. Appl. Microbiol. Biotechnol. 76 (6), 1245-1253. doi:10.1007/ s00253-007-1130-6

Zupančič, Š., Rijavec, T., Lapanje, A., Petelin, M., Kristl, J., and Kocbek, P. (2018). Nanofibers with Incorporated Autochthonous Bacteria as Potential Probiotics for Local Treatment of Periodontal Disease. Biomacromolecules 19 (11), 4299-4306.

Conflict of Interest: The authors declare that the research was conducted in the absence of any commercial or financial relationships that could be construed as a potential conflict of interest.

Copyright (C) 2021 Deev, Rybkin, Rijavec and Lapanje. This is an open-access article distributed under the terms of the Creative Commons Attribution License (CC BY). The use, distribution or reproduction in other forums is permitted, provided the original author(s) and the copyright owner(s) are credited and that the original publication in this journal is cited, in accordance with accepted academic practice. No use, distribution or reproduction is permitted which does not comply with these terms. 